JURNAL RISET MAHASISWA AKUNTANSI (JRMA)

Volume 8, No. 1, Tahun 2020

e-ISSN : 2715 - 7016

\title{
PENGARUH PENGAWASAN KEUANGAN DAN PENYAJIAN LAPORAN KEUANGAN TERHADAP KINERJA PEMERINTAH BERKONSEP VALUE FOR MONEY PADA PEMERINTAH KOTA MALANG (Studi Pada Badan Pengelola Keuangan dan Aset Daerah Kota Malang)
}

\author{
Natalia Elda \\ Email: eldajehanu@gmail.com \\ Sulistyo \\ Eris Dianawati \\ Program Studi Akuntansi, Fakultas Ekonomika dan Bisnis, Universitas Kanjuruhan Malang
}

\begin{abstract}
ABSTRAK
Penelitian ini bertujuan untuk menguji dan menjelaskan pengaruh Pengawasan Keuangan dan Penyajian Laporan Keuangan terhadap Kinerja Pemerintah Berkonsep Value For Money Kota Malang. Model analisis data yang digunakan yaitu regresi linear berganda. Pengambilan sampel dilakukan dengan metode purposive sampling yaitu pengambilan sampel yang didasarkan atas kriteria tertentu untuk dijadikan responden dalam penelitian ini. Pengumpulan data dalam penelitian ini menggunakan kuesioner yang dibagikan kepada pegawai Badan Pengelola Keuangan dan Aset Daerah yang berjumlah 46 kuesioner atau (92\%). Pengujian asumsi klasik meliputi uji multikolinearitas, uji heteroskedastisitas, uji autokorelasi dan uji normalitas. Pengujian hipotesis menggunakan uji F dan uji t. Berdasarkan hasil penelitian analisis data dengan bantuan SPSS 16.00 menunjukkan bahwa 1) Terdapat pengaruh secara signifikan antara Pengawasan Keuangan dan Penyajian Laporan Keuangan terhadap Kinerja Pemerintah Berkonsep Value For Money. 2) Terdapat pengaruh yang positif dan signifikan antara Pengawasan Keuangan terhadap Kinerja Pemerintah berkonsep Value For Money. 3) Terdapat Pengaruh yang positif dan signifikan antara Penyajian Laporan Keuangan terhadap kinerja pemerintah berkonsep value for money.
\end{abstract}

Kata kunci: Pengawasan, Penyajian, dan Kinerja pemerintah.

ABSTRACT

This study aims to examine and explain the effect of Financial Supervision and Presentation of Financial Statements on Government Performance Conceptual Value for Money in Malang. The data analysis model used is multiple linear regression. Sampling is done by purposive sampling method, which is sampling based on certain criteria to be used as respondents in this study. Data collection in this study used a questionnaire that was distributed to employees of the Regional Financial and Asset Management Agency, amounting to 46 questionnaires or (92\%). Classical assumption testing includes multicollinearity test, heteroscedasticity test, autocorrelation test and normality test. Hypothesis testing using the F test and $t$ test. Based on the results of data analysis research with the help of SPSS 16.00 shows that 1) There is a significant influence between Financial Supervision and Presentation of Financial Statements on Government Performance Concepts Value for Money. 2) There is a positive and significant influence between Financial Supervision on the Performance of the Government concept of 
Natalia Elda, Pengaruh Pengawasan Keuangan Dan Penyajian Laporan Keuangan Terhadap Kinerja

Pemerintah Berkonsep Value For Money Pada Pemerintah Kota Malang

Value For Money. 3) There is a positive and significant effect between the Presentation of Financial Statements on the government's performance concept of value for money.

Keywords: Supervision, Presentation, and Government Performance.

\section{PENDAHULUAN}

Kinerja instansi pemerintah saat ini kini menjadi sorotan dengan semakin tingginya kesadaran masyarakat terhadap penyelengaraan administrasi publik (Mardiasmo, 2012). Masyarakat sering menilai organisasi sebagai suatu organisasi yang hanya melakukan pemborosan atau inefesiensi dalam alokasi belanja yang berorientasi pada kepentingan publik.

Pengukuran kinerja pemerintah daerah ditinjau dari kinerja keuangan disebut dengan value for money. Value for money (VFM) adalah konsep pengelolaan organisasi sektor publik yang mendasarkan pada tiga elemen utama, yaitu ekonomi, efisiensi, dan efektivitas

Akuntasi sektor publik merupakan sorotan masyarakat karena pengelolaan anggaran yang tidak efisien, kebocoran dana, pemborosan dana, dan selalu merugi. Value for money merupakan prinsip yang digunakan sebagai bentuk pengelolaan anggaran yang baik. Perwujudan prinsip value for money diyakini dapat memperbaiki kinerja pada sektor pemerintah. Setiap instansi pemerintah seharusnya bisa dapat merubah sejumlah hal yang menjadi penyebab bahwa pelaksanaan pengelolaan anggaran yang tidak berdasar pada value for money. Value for money harus dilakukan dengan baik dalam pelaksanaan pengelolaan keuangan daerah karena dalam konteks otonomi daerah, value for money merupakan penghubung untuk mengantar pemerintah daerah mencapai good governance yaitu pemerintah daerah yang efektif, ekonomis, dan efisien berarti tingkat pencapaian program dengan target yang ditetapkan.

Pengukuran kinerja pemerintah dengan menggunakan pengukuran value for money. Kinerja pemerintah harus diukur dari sisi input, output, dan outcome (Mu'arif:2013). Tujuan pengukuran value for money diantaranya mengukur tingkat keekonomisan dalam alokasi sumber daya, efisiensi dalam penggunaan sumber daya dan hasil yang maksimal, serta efektifitas dalam pengunaan sumber daya tersebut.

Pengukuran menggunakan metode Value for Money (VFM), pemerintah bahkan masyarakat tidak hanya dapat mengukur besarnya biaya barang dan jasa, tetapi dengan menggunakan Value for Money pemerintah juga dapat memperhitungkan kualitas penggunaan sumber daya, ketepatan waktu, dan kenyamanan untuk dapat menilai tingkat ekonomi, efisiensi, dan efektivitas pelaksanaan suatu program.

Fenomena terkait Kinerja pemerintah Kota Malang ditinjau dari Value for Money pertama, dapat dilihat pada Laporan Realisasi Anggaran. Laporan Realisasi Anggaran daerah tahun 2014 pada item alokasi pembiayaan diperoleh rasio efesiensi 102.2\%. (LRA PPKD Kota Malang Thn. 2014). Hal ini menunjukkan kinerja pemerintah Kota Malang pada sektor keungan periode tersebut masih belum maksimal sebab ditinjau dari realisasi penerimaan daerah dan realisasi pengeluaran daerah pada item pembiayaan masih belum efisien dengan ketentuan apabila nilai rasio efeisiensi diatas 100\% menunjukan bahwa anggaran tersebut tidak efisien. Kedua, Laporan Realisasi Anggaran daerah tahun 2014, anggaran pendapatan daerah dari pendapatan hibah diperoleh rasio efektivitas $44,5 \%$. Hal ini menunjukkan kinerja pemerintah Kota Malang pada sector keungan periode tersebut masih belum maksimal sebab ditinjau dari anggaran pendapatan daerah dan realisasi pendapatan daerah dari pendapatan hibah masih belaum efektiv dengan ketentuan apabila nilai rasio efektivitas kurang 100\% menunjukkan bahwa anggaran tersebut kurang efektiv.

Fenomena lain terkait pengelolaan keuangan yang penulis kutip (Antara Jatim, 23 Januari 2016) Rendahnya pengawasan keuangan di pemerintahan Kota Malang berdampak 
pada pembengkakan dana pada sector pembangunan infrastruktur. Sebagai contoh anggaran pembangunan jembatan Kedungkandang Malang membengkak. Selain itu, pembangunan pasar Gadang yang mandek akibat pembengkakan anggaran (surya.co.id, 4 April 2019). Dua persoalan tersebut mengindikasikan bahwa pengawasan internal pemerintah Kota Malang kurang maksimal. Padahal, pengawasan pada sector keuangan berdampak positif pada kinerja pemerintahan.

Berdasarkan fenomena diatas dapat disimpulkan bahwa kinerja pemerintah Kota Malang dinilai kurang maksimal sehingga tujuan dari pemerintah Kota Malang belum tercapai, masih banyaknya perencanaan yang belum selesai, ketidakmampuan dalam menyusun indikator kinerja, dan ketidakselarasan antara perencanaan dengan penggangaran.

Pemerintah Kota Malang, penyajian laporan keuangan disajikan secara baik hal ini dibuktikan dengan penilaian wajar tanpa pengecualian dari Badan Pemeriksaan Keuangan (BPK) dikutip penulis dari (Tribunjatim Edisi Minggu 8 September 2018). Namun, kendala yang dialami oleh masyarakat Kota Malang adalah kesulitan untuk mengakses hasil laporan keuangan serta memperoleh laporan keuangan yang menyajikan data dengan bahasa yang mudah dipahami. Oleh karena itu, dibutuhkan sosialisasi yang baik dan berkesinambuangan agar penyajian laporan keuangan daerah dipahami oleh masyarakat.

Berdasarkan uraian diatas maka maka penulis tertarik untuk melakukan penelitian lebih lanjut mengenai permasalahan yang terjadi dengan judul penelitian “Pengaruh Pengawasan Keuangan Dan Penyajian Laporan Keuangan Terhadap Kinerja Pemerintah Berkonsep Value For Money Pada Pemerintah Kota Malang"

\section{TINJAUAN PUSTAKA}

Menurut Bastian (2010) Kinerja pemerintah yaitu suatu gambaran mengenai tingkat pencapaian sasaran ataupun tujuan instansi pemerintah sebagai penjabaran dari visi, misi dan strategi pemerintah yang mengindikasikan tingkat keberhasilan dan kegagalan pelaksanaan suatu kegiatan sesuai program dan kebijakan yang ditetapkan. Tujuan pelaksanaan Value For Money pada kinerja pemerintah daerah adalah ekonomi: hemat/cermat dalam pengadaan dan alokasi sumber daya; efisiensi: berdaya guna dalam penggunaan sumber daya; efektivitas: berhasil guna dalam arti mencapai tujuan dan sasaran; equity: keadilan dalam mendapatkan pelayanan publik dan equality: kesetaraan dalam penggunaan sumber daya. Konsep Value For Money sebagai penghargaan terhadap nilai uang, hal ini berarti bahwa setiap rupiah harus dihargai secara layak dan digunakan sebaik-baiknya. Kinerja pemerintah tidak dapat dinilai dari sisi output yang dihasilkan saja, akan tetapi harus mempertimbangkan input, output, outcome secara bersama-sama. Indikator kinerja pada value for money berpusat pada ekonomi, efisiensi, dan efektivitas program dan kegiatan atau yang dikenal dengan $3 \mathrm{E}$.

Pengawasan (controlling) adalah proses pemantauan kegiatan untuk menjaga bahwa suatu kegiatan dilaksanakan terarah dan menuju tercapainya tujuan yang telah direncanakan dengan mengadakan penilaian, pengambilan tindakan yang dapat mendukung pencapaian hasil yang dapat diharapkan sesuai dengan kinerja yang telah ditetapkan tersebut (Anugriany, 2017). Pengawasan keuangan dalam kinerja pemerintah mencakup segenap kegiatan untuk meyakinkan dan menjamin agar penyelenggaraan suatu kegiatan tidak menyimpang dari tujuan serta rencana yang telah digariskan dan perintah (aturan) yang diberikan. Pengawasan atas penyelenggaraan pemerintah daerah adalah proses kegiatan yang ditujukan untuk menjamin agar pemerintah daerah berjalan secara efektif dan efisien dengan rencana dan ketentuan peraturan perundang-undangan.

Penyajian laporan keuangan pemerintah merupakan hak publik yang harus diberikan oleh pemerintah, baik pusat maupun daerah. Hak publik atas informasi keuangan muncul sebagai konsekuensi konsep pertanggung jawaban publik mensyaratkan organisasi untuk memberikan laporan keuangan sebagai bukti pertanggung jawaban dan pengelolaan (Mardiasmo, 2012). Tujuan laporan keuangan berdasarkan Peraturan Perundangan No. 71 tahun 2010 dijelaskan bahwa pelaporan keuangan sebagai pertanggung jawaban pengelolaan 
sumber daya serta pelaksanaan kebijakan yang dipercayakan kepada entitas pelaporan keuangan dalam mencapai tujuan yang telah ditetapkan secara periodik, membantu mengevaluasi pelaksanaan kegiatan entitas pelaporan dalam satu periode pelaporan sehingga memudahkan fungsi perencanaan, pengelolaan dan pengendalian atas seluruh aset, kewajiban dan ekuitas dana pemerintah untuk kepentingan masyarakat. Berdasarkan Peraturan Perundang No.71 Tahun 2010 dijelaskan bahwa laporan keuangan disusun untuk menyediakan informasi yang relevan mengenai posisi keuangan dan seluruh transaksi yang dilakukan oleh suatu entitas pelaporan selama satu periode pelaporan, menyajikan setiap fakta secara jujur, informasi yang andal,dapat dibandingkan serta dipahami seluruh pengguna laporan keuangan. Pemerintah daerah harus bisa menyusun laporan keuangan sesuai standar akuntansi yang berterima umum dan memenuhi karakteristik kualitatif laporan keuangan. Semakin baik penyajian laporan keuangan tentu akan memperjelas laporan keuangan pemerintah daerah karena semua transaksi laporan keuangan dilakukan sesuai dengan peraturan yang ada dan akan disajikan dengan lengkap dan jujur dalam laporan keuangan pemerintah.

\section{METODE PENELITIAN}

Penelitian ini menggunakan metode kuantitatif. Penelitian kuantitatif dapat diartikan metode penelitian yang berlandaskan pada filsafat positivisme, untuk meneliti pada populasi dan sampel tertentu, pengumpulan data menggunakan instrumen penelitian, analisis data bersifat kuantitatif dengan tujuan untuk menguji hipotesis yang telah ditetapkan (Sugiyono, 2015:11).

Penelitian ini merupakan jenis penelitian explanatory research. Penelitian eksplanatory bermaksud memberikan penjelasan hubungan kasualitas antara variabel-variabel melalui pengujian hipotesis. Penelitian ini dilakukan untuk mengetahui pengaruh pengawasan keuangan dan penyajian laporan keuangan terhadap kinerja pemerintah berkonsep value for money. Ruang lingkup penelitian ini dilakukan pada Badan Pengelola Keuangan dan Aset Daerah (BPKAD) Kota Malang. Data yang diperoleh dalam penelitian ini adalah data primer berupa kuesioner yang diperoleh langsung dari responden yang bekerja di BPKAD Kota Malang.

Populasi adalah wilayah generalisasi yang terdiri dari obyek/subyek yang mempunyai karakteristik tertentu yang ditetapkan oleh peneliti untuk dipelajari dan kemudian tarik kesimpulannya (Sugiyono, 2015). Dalam penelitian ini yang menjadi populasi adalah pegawai pada Badan Pengelola Keuangan dan Aset Daerah (BPKAD) Kota Malang yang berjumlah 46 orang.

Sampel merupakan bagian dari populasi yang ingin diteliti dan ditarik kesimpulannya (Sugiyono, 2016). Penelitian ini menggunakan metode purposive sampling. Sampling purposive adalah teknik penetuan sampel dengan pertimbangan tertentu (Sugiyono, 2015:126). Kriteria yang digunakan dalam penelitian ini adalah staf keuangan yang bekerja di BPKAD Kota Malang, memiliki masa kerja minimal satu tahun, berlatar belakang pendidikan ekonomi/akuntansi minimal D3.

\section{HASIL ANALISIS}

Deskripsi hasil penelitian yang diperoleh dari pengumpulan data dengan instrumen penelitian skala likert. Pemaparan tersebut mencakup mean, median, standart deviation, skor minimum, dan skor maksimum. Jika Y menyatakan variabel terikat (Kinerja pemerintah berkonsep value for money) maka $\mathrm{X}$ menyatakan variabel bebas yang terdiri atas $\mathrm{X}_{1}$ (Pengawasan Keuangan), $\mathrm{X}_{2}$ (Penyajian Laporan Keuangan).

Berdasarkan hasil perhitungan statistik dengan bantuan software software SPSS 16.00 for windows diperoleh tabel Anova yang menunjukkan uji F statistik. Adapun hasil uji F pada tabel Anova dapat dilihat sebagai berikut: 


\section{Uji F (Uji Signifikan Secara Simultan)}

\begin{tabular}{|c|c|c|c|c|c|}
\hline \multicolumn{6}{|c|}{ Anova $^{b}$} \\
\hline Model & $\begin{array}{l}\text { Sum of } \\
\text { Squares }\end{array}$ & Df & $\begin{array}{l}\text { Mean } \\
\text { Square }\end{array}$ & $\mathrm{F}$ & Sig. \\
\hline $\begin{array}{l}1 \text { Regressio } \\
\mathrm{n}\end{array}$ & 803.909 & 2 & $\begin{array}{l}401.95 \\
4\end{array}$ & 13.181 & $.000^{\mathrm{a}}$ \\
\hline Residual & 1311.243 & 43 & 30.494 & & \\
\hline Total & 2115.152 & 45 & & & \\
\hline $\begin{array}{l}\text { A. Predict } \\
\text { Keuangan, } \mathrm{P}\end{array}$ & $\begin{array}{l}\text { ors: (Con } \\
\text { engawasan }\end{array}$ & $\begin{array}{l}\mathrm{Astar} \\
\mathrm{Ke}\end{array}$ & $\begin{array}{l}\text { Pen } \\
\text { gan }\end{array}$ & ian & pors \\
\hline B. Dependen & at Variable: & $\mathrm{Ki}$ & Pem & ntah & \\
\hline
\end{tabular}

Hasil tes Anova diperoleh nilai F sebesar 13. 181 dengan nilai signifikan uji F sebesar 0,000 lebih kecil alpha 0,05. Jadi, dimana diisyaratkan nilai signifikan F lebih kecil dari 0,05. Jadi dapat dikemukakan bahwa hipotesis pertama yang menyatakan variabel pengawasan keuangan dan penyajian laporan keuangan secara simultan berpengaruh terhadap kinerja pemerintah berkonsep value for money sehingga $\mathrm{H}_{1}$ "dapat diterima".

Berdasarkan hasil penelitian statistic dengan bantuan SPSS 16.00 for windows diperoleh tabel model summary yang menunjukkan uji F Statistic. Adapun hasil uji F pada tabel berikut ini:

\section{Hasil Analisis Uji-T (uji signifikan secara parsial)}

\begin{tabular}{|c|c|c|c|}
\hline Variabel & $\mathrm{T}$ & Sig & Keterangan \\
\hline (Constant) & 2.255 & .029 & Signifikan \\
\hline $\begin{array}{l}\text { Pengawasan } \\
\text { Keuangan }\left(\mathrm{X}_{1}\right)\end{array}$ & 2.345 & .024 & Signifikan \\
\hline $\begin{array}{l}\text { Penyajian Laporan } \\
\text { Keuangan }\left(\mathrm{X}_{2}\right)\end{array}$ & 2.895 & .006 & Signifikan \\
\hline
\end{tabular}

Hipotesis penelitian untuk menguji hipotesis kedua $\left(\mathrm{H}_{2}\right)$ adalah sebagai berikut: Pengambilan keputusan untuk pengujian hipotesis yang diajukan adalah: Berdasarkan tabel diatas menunjukkan nilai variabel nilai $t$ untuk variabel pengawasan keuangan $\left(X_{1}\right)$ sebesar 2.345 dengan tingkat signifikan sebesar 0,024. Karena tingkat signifikannya lebih kecil dari 0,05 maka variabel Pengawasan Keuangan $\left(\mathrm{X}_{1}\right)$ berpengaruh terhadap kinerja pemerintah berkonsep value for money $(\mathrm{Y})$ sehinga $\mathrm{H}_{2}$ "dapat diterima”.

Hipotesis penelitian untuk menguji nilai untuk variabel penyajian laporan keuangan $\left(\mathrm{X}_{2}\right)$ sebesar 2.895 dengan tingkat signifikan sebesar 0,006. Karena tingkat signifikan lebih kecil dari 0,05 maka variabel penyajian laporan keuangan $\left(\mathrm{X}_{2}\right)$ berpengaruh terhadap kinerja pemerintah berkonsep value for money (Y) sehingga $\mathrm{H}_{3}$ " dapat diterima".

\section{PEMBAHASAN}

\section{Pengaruh Pengawasan Keuangan Dan Penyajian Laporan Keuangan Terhadap Kinerja} Pemerintah Berkonsep Value For Money

Hasil penelitian uji simultan yaitu variabel Pengawasan Keuangan $\left(X_{1}\right)$ dan Penyajian Laporan Keuangan $\left(\mathrm{X}_{2}\right)$ dalam penelitian ini berpengaruh terhadap kinerja pemerintah berkonsep value for money. Dengan demikian, hipotesis pertama yang menyatakan pengawasan keuangan dan penyajian laporan keuangan secara simultan berpengaruh positif dan signifikan terhadap kinerja pemerintah berkonsep value for money, terbukti dan diterima. Hasil penelitian ini menunjukkan bahwa pengawasan keuangan yang baik memudahkan penyajian laporan keuangan bagi para pengguna ternyata akan mampu meningkatkan kinerja pemerintah pada pengelolaan keuangan.

Hasil analisis uji simultan menunjukkan bahwa pengawasan keuangan dan penyajian laporan keuangan secara bersama-sama mempengaruhi pengaruh yang signifikan terhadap 
kinerja pemerintah. Selain Pengawasan Keuangan $\left(X_{1}\right)$ dan Penyajian Laporan Keuangan $\left(X_{2}\right)$ juga ikut ditentukan oleh faktor lain yang tidak dikaji dalam penelitian ini. Untuk mencapai kinerja pemerintah yang maksimal, maka kita harus memahami faktor-faktor yang mempengaruhi kinerja pemerintah tersebut. Kinerja pemerintah akan semakin meningkat ketika faktor-faktor yang mempengaruhi berpengaruh secara selaras dan positif.

Laporan keuangan disusun untuk menyediakan informasi yang relevan mengenai posisi keuangan dan seluruh transaksi yang dilakukan oleh suatu entitas pelaporan dalam suatu periode. Laporan keuangan terutama digunakan untuk membandingkan realisasi pendapatan, belanja, transfer dan pembiayaan dengan anggaran yang telah ditetapkan, menilai kondisi keuangan, mengevaluasi, efektivitas dan efisiensi suatu entitas pelaporan dan membantu menentukan ketentuannya terhadap undang-undang.

Penerapan anggaran Pemerintah Kota Malang dalam hal ini Khususnya Badan Pengelola Keuangan dan Aset Daerah (BPKAD) Kota Malang harus melakukan berbagai persiapan seperti penyusunan sistem akuntansi yang sesuai standar pemerintah, sumber daya manusia dan tersedianya sarana dan prasarana untuk menunjang pelaksanaan kegiatan pemerintah. Karena melaui pengawasan keuangan serta penyajian laporan keuangan, kualitas kinerja pemerintah ditingkatkan. Kualitas kinerja pemerintah yang baik bermanfaat untuk mengetahui efisiensi dan efektivitas pelayanan publik yang disediakan manajemen dan pengendalian aset negara, perencanaan, penyusunan program dan anggaran.

Berdasarkan hasil pengujian variabel pengawasan keuangan $\left(X_{1}\right)$ hasil pengujian $H_{1}$ ditemukan bahwa variabel pengawasan keuangan berpengaruh signifikan terhadap kinerja pemerintah berkonsep value for money. Hasil penelitian ini diperkuat oleh penelitian wiguna et al (2015) sukhemi (2016), I Desak Nyoman Tri Wandari (2015), Darwanis satria (2014) yang menyimpulkan bahwa pengawasan keuangan berpengaruh secara simultan terhadap kinerja pemerintah berkonsep value for money.

Berdasarkan hasil pengujian variabel penyajian laporan keuangan $\left(\mathrm{X}_{2}\right)$ hasil pengujian $\mathrm{H}_{2}$ ditemukan bahwa penyajian laporan keuangan memilki pengaruh signifikan terhadap kinerja pemerintah. Hasil yang diperoleh diperkuat dengan nilai koefisien regresi yang menandakan bahwa semakin baik penyajian laporan keuangan maka akan semakin meningkat kinerja pemerintah. Hasil pengujian ditemukan bahwa variabel penyajian laporan keuangan berpengaruh terhadap kinerja pemerintah.

Pengaruh pengawasan Keuangan terhadap Kinerja Pemerintah berkonsep Value For Money.

Berdasarkan hasil dari variabel pengawasan keuangan $\left(\mathrm{X}_{1}\right)$, hasil pengujian $\mathrm{H}_{2}$ ditemukan bahwa variabel pengawasan keuangan berpengaruh signifikan terhadap kinerja pemerintah berkonsep value for money. Signifikan disini berarti hipotesis diterima. Hasil penelitian ini menunjukkan bahwa pengawasan keuangan yang baik akan berimpikasi terhadap peningkatan kinerja pemerintah terutama dalam pengelolaan keuangan.

Hasil penelitian ini diperkuat dengan penelitian yang dilakukan oleh Desak Nyoman Tri Wandari (2015) menunjukkan bahwa pengawasan keuangan berpengaruh positif signifikan terhadap kinerja pemerintah dengan konsep value for money pada instansi pemerintah di Kabupaten Buleleng, dan sejalan dengan penelitian Resky Mulya Anugriani (2014) yang menyimpulkan bahwa pengawasan keuangan berpengaruh signifikan dan positif terhadap kinerja pemerintah berkonsep value for money.

Pengawasan keuangan merupakan salah satu fungsi manajemen yang harus dilaksanakan dengan baik dalam pelaksanaan kegiatan pemerintah. Pelaksanaaan pengawasan keuangan daerah dapat menjadi sarana untuk mengetahui apakah suatu instansi pemerintah telah melakukan pengelolaan secara baik dan benar. Dengan adanya pelaksanaan pengawasan keuangan akan membantu mengontrol pelaksanaan kegiatan pemerintah baik dalam proses perencanaan, pelaksanaan maupun pertanggungjawaban, dengan demikian dapat mencapai keberhasilan sesuai dengan rencana dan peraturan perundang-undangan yang telah ditetapkan sehingga akan meningkatkan kinerja pemerintah daerah (Purnama, 2016). 
Hasil ini menunjukkan dengan adanya pengawasan yang dilakukan oleh pemerintah Kota Malang maka mampu meningkatkan kinerja pemerintah daerah dalam pengelolaan keuangan sehingga mampu melaksanakan tugas-tugasnya sesuai dengan tugas pokok dan fungsi masing-masing dan meminimalisir penyimpangan-penyimpangan yang terjadi. Disamping itu fungsi yang dilaksanakan oleh pemerintah Kota Malang tidak semerta-merta hanya melakukan pengawasan tetapi juga kegiatan yang dilaksanakan dalam bentuk pembinaan pegawai sehingga pegawai mau bekerja dengan giat melaksanakan tugas-tugasnya sesuai dengan program serta aturan dan kaidah-kaidah yang berlaku.

\section{Pengaruh penyajian laporan keuangan terhadap kinerja pemerintah berkonsep value for money}

Berdasarkan hasil penelitian variabel Penyajian Laporan Keuangan hasil pengujian disimpulkan bahwa penyajian laporan keuangan secara signifikan berpengaruh terhadap kinerja pemerintah berkonsep value for money. Signifikan disini berarti hipotesis diterima. Ini berarti penyajian laporan keuangan berpengaruh signifikan terhadap kinerja pemerintah berkonsep value for money dengan demikian hipotesis ketiga yang menyatakan penyajian laporan keuangan berpengaruh signifikan terhadap kinerja pemerintah berkonsep value for money terbukti. Hasil penelitian ini menunjukkan bahwa dengan menyajikan laporan keuangan akan berimpikasi terhadap peningkatan kinerja pemerintah terutama dalam pengelolaan keuangan.

Hasil penelitian ini diperkuat oleh penelitian yang dilakukan oleh Nyoman Trisna, Putu Sri Wahyuni (2014), Darwanis satria (2014), Sanjaya,dkk (2014), Sukhemi (2016) menyimpulkan bahwa penyajian laporan keuangan berpengaruh signifikan terhadap kinerja pemerintah berkonsep value for money.

Hasil yang diperoleh diperkuat dengan nilai koefisien regresi bertanda positif yang menandakan bahwa semakin baik penyajian laporan keuangan maka akan semakin meningkatkan kinerja pemerintah. Dalam pembuatan laporan keuangan, pemerintah harus menyampaikan secara jelas dan detail mengenai data-data dan informasi secara relevan. Laporan keuangan yang telah dibuat oleh pemerintah akan berguna untuk pihak-pihak tertentu yang akan membuat keputusan-keputusan ekonomi.

Komponen laporan keuangan pada Badan Pengelola Keuangan dan Aset Daerah (BPKAD) Kota Malang tahun 2015 sesuai dengan peraturan Pemerintah Nomor 71 Tahun 2010 dijelaskan bahwa komponen-komponen yang terdapat dalam satu set laporan keuangan terdiri dari laporan pelaksanaan anggaran (budgetary reports) dan laporan finansial, sehingga seluruh komponen dalam penyajian laporan keuangan disajikan secara jelas, jujur, dan terbuka kepada masyarakat guna memperoleh informasi mengenai penyajian laporan keuangan.

Laporan keuangan sebenarnya dibutuhkan setiap instansi untuk meningkatkan ataupun mengevaluasi kinerjanya. Setiap kegiatan yang dilakukan oleh BPKAD Kota Malang harus dapat dipertanggungjawabkan terhadap masyarakat sebagai pemegang kekuasaan di daerah. Salah satu media yang memenuhi hal tersebut adalah dengan menyajikan laporan keuangan yang handal dan tepat waktu serta dapat dipublikasikan kepada masyarakat. Laporan keuangan BPKAD Kota Malang disusun untuk menyediakan informasi yang relevan mengenai posisi keuangan dan seluruh transaksi yang dilakukan dalam satu periode. Kinerja pemerintah dapat dikatakan baik, tentunya informasi tersebut harus dipublikasikan kepada publik. Ketika masyarakat membutuhkan informasi menggenai informasi yang berkaitan dengan kinerja suatu instansi, maka dapat diasumsikan bahwa kepercayaan masyarakat terhadap instansi tersebut dapat terbentuk.

\section{KESIMPULAN DAN SARAN.}

Berdasarkan hasil penelitian yang telah dijelaskan tentang Pengaruh Pengawasan Keuangan dan Penyajian Laporan Keuangan terhadap Kinerja Pemerintah Berkonsep Value For Money Kota Malang, maka dapat disimpulkan bahwa berdasarkan hasil analisis regresi linear 
berganda menunjukkan bahwa hasil penelitian membuktikan bahwa variabel Pengawasan Keuangan dan Penyajian Laporan Keuangan secara bersama-sama mempunyai pengaruh terhadap Kinerja Pemerintah Berkonsep Value For Money Kota Malang. Adapun secara parsial pengawasan keuangan berpengaruh signifikan terhadap kinerja pemerintah berkonsep value for money, dan penyajian laporan keuangan berpengaruh signifikan terhadap kinerja pemerintah berkonsep value for money.

Berdasarkan hasil penelitian ini, maka saran yang diajukan adalah sebagai berikut: Bagi Mahasiswa, Hasil penelitian ini diharapkan mahasiswa dapat menjadikannya sebagai nilai tambah dalam ilmu pengetahuan dan wawasan terutama yang berkaitan dengan Pengaruh Pengawasan Keuangan dan Penyajian Laporan Keuangan terhadap Kinerja Pemerintah berkonsep Value For Money. Bagi Pemerintah,

Hasil penelitian ini menunjukkan Pengawasan Keuangan dan Penyajian Laporan Keuangan berpengaruh terhadap Kinerja Pemerintah berkonsep Value For Money. Oleh karena itu, bagi pihak pemerintah Kota Malang diharapkan untuk meningkatkan sumber daya manusia khususnya bidang akuntansi dengan mengadakan pelatihan-pelatihan secara rutin terkait pengelolaan keuangan pemerintah serta megefektifkan pengendalian internal agar laporan keuangan yang dihasilkan dapat disajikan secara lengkap dan tepat waktu. Bagi Peneliti Selanjutnya, diharapkan sebaiknya dapat menambah atau mengembangkan beberapa hal yakni metode pengumpulan data (wawancara), memperluas obyek penelitian, dan peneliti selanjutnya dapat menambahkan variabel-variabel lain yang dapat mempengaruhi kinerja pemerintah berkonsep value for money.

\section{DAFTAR PUSTAKA}

Bastian, Indra. 2010. Akuntansi Sektor Publik Suatu Pengantar Edisi Ketiga. Penerbit Erlangga, Jakarta.

Ghozali,Imam. (2013). Aplikasi Analisis Multivariate dengan Program IBM SPSS 22. Semarang : Universitas di Ponegoro.

Mardiasmo. 2012. Akuntansi Sektor Publik. Edisi Empat. Yogyakarta: ANDI

Nordiawan, Deddi. 2010. Akuntansi Sektor Publik. Jakarta: Salemba Empat

Sarwoko, Endi. (2018). Statistik Inferensi Untuk Ekonomi Dan Bisnis. Penerbit Yogyakarta. 